\title{
Mass Change Prediction Model of Concrete Subjected to Sulfate Attack
}

\author{
Kwang-Myong Lee, ${ }^{1}$ Su-Ho Bae, ${ }^{2}$ Jae-Im Park, ${ }^{3}$ and Soon-Oh Kwon ${ }^{2}$ \\ ${ }^{1}$ Department of Civil and Environmental Engineering, Sungkyunkwan University, Suwon 440-746, Republic of Korea \\ ${ }^{2}$ Department of Civil Engineering, Andong National University, Andong 760-749, Republic of Korea \\ ${ }^{3}$ Metropolitan Transit System Research Division, Korea Railroad Research Institute, Uiwang 437-757, Republic of Korea
}

Correspondence should be addressed to Su-Ho Bae; shbae@andong.ac.kr

Received 5 September 2014; Accepted 5 October 2014

Academic Editor: Sang-Youl Lee

Copyright (C) 2015 Kwang-Myong Lee et al. This is an open access article distributed under the Creative Commons Attribution License, which permits unrestricted use, distribution, and reproduction in any medium, provided the original work is properly cited.

\begin{abstract}
The present study suggested a mass change prediction model for sulfate attack of concrete containing mineral admixtures through an immersion test in sulfate solutions. For this, 100\% OPC as well as binary and ternary blended cement concrete specimens were manufactured by changing the types and amount of mineral admixture. The concrete specimens were immersed in fresh water, $10 \%$ sodium sulfate solution, and $10 \%$ magnesium sulfate solution, respectively, and mass change of the specimens was measured at $28,56,91,182$, and 365 days. The experimental results indicated that resistance of concrete containing mineral admixture against sodium sulfate attack was far greater than that of $100 \%$ OPC concrete. However, in terms of resistance against magnesium sulfate attack, concrete containing mineral admixture was lower than $100 \%$ OPC concrete due to the formation of magnesium silicate hydrate (M-S-H), the noncementitious material. Ultimately, based on the experimental results, a mass change prediction model was suggested and it was found that the prediction values using the model corresponded relatively well with the experimental results.
\end{abstract}

\section{Introduction}

Concrete structures exposed to soil, groundwater, and seawater environments are subject to performance degradation due to sulfate attack. The harmful ions including sulfate ion penetrate into concrete and react with calcium hydroxide and calcium aluminate hydrate to form expansion hydration products such as gypsum and ettringite. This may lead to cracking and softening action and eventually lower durability of concrete structures [1-4]. In case of sodium sulfate $\left(\mathrm{Na}_{2} \mathrm{SO}_{4}\right)$ attack, the reaction of sulfate ion $\left(\mathrm{SO}_{4}{ }^{2-}\right)$ and calcium hydroxide generated by cement hydration forms gypsum, which results in softening and loss of strength of cement paste. In this case, the gypsum reacts with calcium aluminate hydrate $\left(\mathrm{C}_{4} \mathrm{AH}_{13}\right)$, monosulfate $\left(\mathrm{C}_{4} \mathrm{~A} \overline{\mathrm{S}} \mathrm{H}_{12}\right)$, and tricalcium aluminate $\left(\mathrm{C}_{3} \mathrm{~A}\right)$ to produce secondary ettringite, which accompanies volume increase, and therefore results in expansion and cracking [5-7]. In case of magnesium sulfate $\left(\mathrm{MgSO}_{4}\right)$ attack, magnesium sulfate and calcium hydroxide react first to form gypsum and brucite $\left(\mathrm{Mg}(\mathrm{OH})_{2}\right)$. Brucite is low in $\mathrm{pH}$ and thus destabilizes C-S-H (calcium silicate hydrate) and ettringite. As a result, magnesium sulfate reacts easily with C-S-H to form gypsum, brucite, and silica gel $\left(\mathrm{S}_{2} \mathrm{H}\right)$. The lime freed by this reaction reacts further with magnesium sulfate instead of reestablishing the $\mathrm{pH}$ and forms more brucite; accordingly the concentration of gypsum and brucite in the paste matrix will increase. As the increased brucite reacts with $\mathrm{S}_{2} \mathrm{H}$, C-S-H gradually loses lime and becomes converted to noncementitious M-S-H $[6,8,9]$.

The chemical reaction mechanism by sulfate is influenced by the numerous controlling parameters, such as concentration of sulfate ions, ambient temperature, types and proportions of cementitious materials, water-binder ratio $(\mathrm{W} / \mathrm{B})$, and curing period $[2,10]$. This is a complex and timedependent phenomenon that takes place over a long time due to the relatively lower diffusivities of sulfate ions that penetrate into concrete. Accordingly, although studies have been conducted for long on the chemical erosion of concrete, 
TABLE 1: Physical properties and chemical composition of cement and mineral admixtures.

\begin{tabular}{lccccccccc}
\hline \multirow{2}{*}{ Type of binder } & \multicolumn{2}{c}{ Physical properties } & \multicolumn{5}{c}{ Chemical composition (\%) } \\
& Specific gravity & Blaine $\left(\mathrm{m}^{2} / \mathrm{kg}\right)$ & $\mathrm{SiO}_{2}$ & $\mathrm{Al}_{2} \mathrm{O}_{3}$ & $\mathrm{Fe}_{2} \mathrm{O}_{3}$ & $\mathrm{CaO}$ & $\mathrm{MgO}^{2}$ & $\mathrm{SO}_{3}$ & $\mathrm{R}_{2} \mathrm{O}$ \\
\hline OPC & 3.15 & 329.0 & 21.1 & 4.6 & 3.5 & 61.8 & 3.2 & 2.1 & 0.9 \\
GGBFS & 2.89 & 489.3 & 34.1 & 16.1 & 0.4 & 42.3 & 4.1 & 2.5 & 0.7 \\
FA & 2.23 & 375.0 & 56.5 & 27.1 & 4.4 & 3.8 & 0.8 & 0.2 & 1.3 \\
SF & 2.20 & 20,000 & 88.7 & 1.8 & 1.8 & 1.5 & 0.8 & 0.1 & 1.0 \\
\hline
\end{tabular}

TABLE 2: $\mathrm{C}_{3} \mathrm{~A}$ content of concretes containing mineral admixtures.

\begin{tabular}{lcccr}
\hline Type of concrete & $100 \%$ OPC & BBC $^{*}$ & TBC1 $^{* *}$ & TBC2 $^{* * *}$ \\
\hline $\mathrm{C}_{3} \mathrm{~A}$ content $(\%)$ & 6.58 & 3.18 & 2.87 & 2.70 \\
\hline
\end{tabular}

${ }^{*} \mathrm{OPC}: \mathrm{GGBFS}=50 \%: 50 \%$.

** OPC: GGBFS : $\mathrm{FA}=40 \%: 40 \%: 20 \%$.

*** OPC: GGBFS : $\mathrm{SF}=50 \%: 45 \%: 5 \%$.

TABLE 3: Physical properties of fine aggregate.

\begin{tabular}{lccccc}
\hline Specimen & Density $\left(\mathrm{g} / \mathrm{cm}^{3}\right)$ & Absorption (\%) & Unit mass $\left(\mathrm{kg} / \mathrm{m}^{3}\right)$ & $\begin{array}{c}\text { Amount of passing } \\
\text { No. 200 sieve }(\%)\end{array}$ & Fineness modulus \\
\hline River sand & 2.60 & 1.47 & 1,597 & 2.2 & 2.43 \\
\hline
\end{tabular}

TABLE 4: Physical properties of coarse aggregate.

\begin{tabular}{lccccc}
\hline Specimen & $G_{\max }(\mathrm{mm})$ & Density $\left(\mathrm{g} / \mathrm{cm}^{3}\right)$ & Absorption $(\%)$ & Unit mass $\left(\mathrm{kg} / \mathrm{m}^{3}\right)$ & Fineness modulus \\
\hline Crushed rock & 20 & 2.65 & 0.58 & 1,648 & 7.27 \\
\hline
\end{tabular}

TABLE 5: Properties of superplasticizer.

\begin{tabular}{lcccc}
\hline Main composition & Specific gravity & $\mathrm{pH}$ & Solid content (\%) & Quantity (\%) (by mass of cement) \\
\hline Polycarbonic acid & 1.05 & 9 & 38 & $0.5 \sim 2.5$ \\
\hline
\end{tabular}

complete verification of the mechanism and establishment of prevention measures are yet to be done.

Meanwhile, a study has been conducted to improve sulfate attack resistance of concrete by utilizing mineral admixture such as fly ash (FA), ground granulated blast furnace slag (GGBFS), and silica fume (SF). Mineral admixtures react with the portlandite $\left(\mathrm{Ca}(\mathrm{OH})_{2}\right)$ liberated during the hydration of cement to form secondary C-S-H gel, which is relatively denser than the primary $\mathrm{C}-\mathrm{S}-\mathrm{H}$ gel, thus resulting in pore refinement. The other beneficial effect of incorporating mineral admixtures into the concrete mixture is the reduction of portlandite and alumina contents in the cementitious material that are essential for the formation of gypsum and ettringite [2, 6, 11-13].

Thus, the purpose of this research is to investigate the influence of mineral admixture on sulfate attack resistance of concrete through an immersion test in sulfate solutions and to suggest a mass change prediction model of concrete subjected to sulfate attack. For this, concrete test specimens with W/Bs of $32 \%$ and $43 \%$ were manufactured using $100 \%$ ordinary portland cement (OPC) concrete as well as binary blended cement (BBC) and ternary blended cement (TBC) concrete mixed with OPC and mineral admixture. Then, according to the JSTM C 7401 [14] sulfate attack resistance was assessed by investigating mass change as per immersion age. Ultimately, based on the experimental results, a mass change prediction model for sulfate attack of concrete was suggested.

\section{Experimental Work}

2.1. Materials Used and Mix Proportions. To manufacture concrete specimens for sulfate resistance test, OPC, FA, GGBFS, and SF were used. The physical properties and chemical compositions of cement and mineral admixtures are given in Table 1 . To use $\mathrm{C}_{3} \mathrm{~A}$ content in concrete, which exerts significant influence on the sulfate attack mechanism, as a key parameter of sulfate attack prediction model, $\mathrm{C}_{3} \mathrm{~A}$ contents of concrete containing a number of mineral admixtures as shown in Table 2 were analyzed. For fine aggregate and coarse aggregate, river sand and crushed rock were used, respectively. Their physical properties are given in Tables 3 and 4. To control fluidity of concrete mixture, air entraining (AE) and high-range water reducing agent of polycarbonic acid were used as a kind of superplasticizer. The properties are as shown in Table 5.

To manufacture concrete specimens for sulfate resistance test, mix proportions for $\mathrm{BBC}$ concrete and two types of 
TABLE 6: Mix proportions of concrete mixtures.

\begin{tabular}{|c|c|c|c|c|c|c|c|c|c|c|c|}
\hline \multirow{3}{*}{$G_{\max }(\mathrm{mm})$} & \multirow{3}{*}{ W/B (\%) } & \multirow{3}{*}{ S/a (\%) } & \multirow{3}{*}{ Cement type } & \multirow{3}{*}{ W } & \multicolumn{6}{|c|}{ Unit mass $\left(\mathrm{kg} / \mathrm{m}^{3}\right)$} & \multirow{3}{*}{ Superplasticizer $(\mathrm{B} \times \%)$} \\
\hline & & & & & & Binder & & & $\mathrm{S}$ & $G$ & \\
\hline & & & & & OPC & GGBFS & FA & SF & J & 0 & \\
\hline \multirow{4}{*}{20} & \multirow{4}{*}{32} & \multirow{4}{*}{42} & OPC & 160 & 500 & 0 & 0 & 0 & 691 & 966 & 1.10 \\
\hline & & & $\mathrm{BBC}$ & 160 & 250 & 250 & 0 & 0 & 684 & 955 & 0.85 \\
\hline & & & $\mathrm{TBC} 1$ & 160 & 200 & 200 & 100 & 0 & 707 & 910 & 1.30 \\
\hline & & & TBC2 & 160 & 250 & 225 & 0 & 25 & 681 & 951 & 1.36 \\
\hline \multirow{4}{*}{20} & \multirow{4}{*}{43} & \multirow{4}{*}{47} & OPC & 165 & 388 & 0 & 0 & 0 & 811 & 925 & 1.00 \\
\hline & & & $\mathrm{BBC}$ & 165 & 194 & 194 & 0 & 0 & 805 & 918 & 0.80 \\
\hline & & & $\mathrm{TBC1}$ & 165 & 155.2 & 155.2 & 77.6 & 0 & 798 & 910 & 1.03 \\
\hline & & & TBC2 & 165 & 194 & 174.6 & 0 & 19.4 & 802 & 915 & 1.23 \\
\hline
\end{tabular}

\begin{tabular}{|c|c|c|c|c|}
\hline $1 \sim 2$ days & & $\sim 26$ days & & $\sim 28$ days \\
\hline Demolding & $\rightarrow$ & $\begin{array}{l}20^{\circ} \mathrm{C}, 60 \% \\
\text { Dry curing }\end{array}$ & $\rightarrow$ & $\begin{array}{l}20^{\circ} \mathrm{C} \\
\text { Water } \\
\text { curing }\end{array}$ \\
\hline
\end{tabular}

FIGURE 1: Pretreatment process of concrete in case of no incrustation.

ternary blended cement (TBC1, TBC2) concrete were determined as shown in Table 6 in addition to $100 \%$ OPC concrete. OPC and GGBFS were used for BBC concrete and FA and SF were additionally used, respectively, for TBC concrete. W/B was $32 \%$ and $43 \%$ and target slumps and air contents of all of the concrete mixtures were $180 \pm 25 \mathrm{~mm}$ and $5.0 \pm 0.5 \%$, respectively.

2.2. Specimen Preparation. Concrete cylinders $(\varnothing 100 \times$ $200 \mathrm{~mm}$ ) were prepared for compressive strength test and sulfate attack test. After cylinders were molded, they were kept inside a constant temperature and humidity chamber over 24 hours. Then, the molds were removed and test specimens for standard curing were cured in a water bath with temperature of $20 \pm 2^{\circ} \mathrm{C}$ until test began. As for test specimens for sulfate solution immersion, pretreatment was conducted as illustrated in Figure 1. In this study, no incrustation specimens were used. Therefore, test specimens were left inside a constant temperature and humidity chamber with temperature of $20 \pm 2^{\circ} \mathrm{C}$ and relative humidity of $60 \pm 5 \%$ until 26 days and then the specimens were cured underwater at $20 \pm 2^{\circ} \mathrm{C}$ until 28 days.

2.3. Test Method for Sulfate Attack Resistance. The test method for chemical resistance of concrete is also specified in the ASTM C 1012 [15]. However, this method is for mortar and therefore, in this study, sulfate attack resistance of concrete was tested according to the "test method for chemical resistance by concrete immersion in solution" of JSTM C 7401 [14]. This method is to assess chemical resistance by immersing test specimens into acid or alkaline solutions for a prescribed period of time and by comparing changes in the measurements against those of standard curing specimens.
Of chemicals proposed for this method, $10 \%$ sodium sulfate and $10 \%$ magnesium sulfate solutions were selected for the test.

In this test, sulfate attack resistance of concrete is assessed in terms of compressive strength ratio as well as mass and length change ratios. For this study, sulfate attack resistance was assessed by mass change ratio as follows:

$$
\text { mass change ratio }(\%)=\frac{W_{i}-W_{c i}}{W_{c i}} \times 100,
$$

where $W_{i}$ is mass of concrete immersed in test solution at the measuring age $(\mathrm{g})$ and $W_{c i}$ is mass of concrete before immersion in test solution $(\mathrm{g})$.

In addition, to investigate microstructure of the concrete degraded by sulfate ion, powder samples were extracted from the sulfate reaction areas of concrete specimens immersed in each solution for 365 days and XRD analysis was conducted on the samples using JCPDS (joint committee on powder diffraction standards) card method.

\section{Results and Discussion}

3.1. Fundamental Properties. Table 7 shows slumps and air contents of fresh concrete as well as compressive strengths of standard cured concrete at 28 days per mix proportions of concrete used in the sulfate attack resistance test. Compressive strengths and slumps of concrete are the mean value for 3 and 2 times, respectively, and air contents are one measured value. Slumps and air contents of all of the concrete mixtures satisfied the target values of $180 \pm 25 \mathrm{~mm}$ and $5.0 \pm 0.5 \%$, respectively. In case of $\mathrm{W} / \mathrm{B}=32 \%$, compressive strength of $\mathrm{BBC}$ concrete and $\mathrm{TBC}$ concrete containing mineral admixture was higher than $100 \%$ OPC concrete. On the other hand, in case of $\mathrm{W} / \mathrm{B}=43 \%$, compressive strength of $\mathrm{BBC}$ concrete and $\mathrm{TBC}$ concrete was found to be generally lower than $100 \%$ OPC concrete. This is because, in concrete containing GGBFS, compressive strength increases regardless of GGBFS replacement ratio in case of high strength concrete with unit binder content of $500 \mathrm{~kg} / \mathrm{m}^{3}$, but, in normal strength concrete with unit binder content of approximately $400 \mathrm{~kg} / \mathrm{m}^{3}$, compressive strength becomes lower than that of OPC concrete when GGBFS replacement ratio exceeds approximately $30 \%$ [16]. 
TABLE 7: Compressive strength, slump, and air content for concrete.

\begin{tabular}{lcccc}
\hline $\begin{array}{l}\text { W/B } \\
(\%)\end{array}$ & $\begin{array}{c}\text { Cement } \\
\text { type }\end{array}$ & $\begin{array}{c}\text { Compressive } \\
\text { strength at 28 } \\
\text { days (MPa) }\end{array}$ & $\begin{array}{c}\text { Slump } \\
(\mathrm{mm})\end{array}$ & $\begin{array}{c}\text { Air } \\
\text { content } \\
(\%)\end{array}$ \\
\hline \multirow{3}{*}{32} & OPC & 49.5 & 196 & 5.2 \\
& BBC & 57.4 & 197 & 4.9 \\
& TBC1 & 54.0 & 205 & 5.2 \\
& TBC2 & 54.6 & 196 & 5.1 \\
\hline \multirow{4}{*}{43} & OPC & 36.6 & 197 & 5.0 \\
& BBC & 26.5 & 203 & 5.2 \\
& TBC1 & 29.5 & 205 & 5.1 \\
& TBC2 & 36.7 & 194 & 5.0 \\
\hline
\end{tabular}

3.2. Mass Change. Table 8 shows charges in the appearance of concrete specimens immersed in $10 \%$ sodium sulfate and $10 \%$ magnesium sulfate solutions for 28,182 , and 365 days. Figures 2 and 3 show mass change ratios of concrete specimens immersed in sulfate solution for $28,56,91,182$, and 365 days according to $\mathrm{W} / \mathrm{B}$.

In case of $\mathrm{W} / \mathrm{B}=32 \%$, all of the concrete specimens immersed in $10 \%$ sodium sulfate solution displayed almost no mass change. This is because the low $\mathrm{W} / \mathrm{B}$ increased density of the microstructure of concrete and therefore slowed down the process of deterioration by sodium sulfate attack. This result indicated that the use of low $\mathrm{W} / \mathrm{B}$ was very effective in suppressing sodium sulfate attack. In case of $\mathrm{W} / \mathrm{B}=43 \%$, the rate of mass decrease in $100 \%$ OPC concrete and BBC concrete was found to increase as the age increased. On the other hand, rate of mass decrease was almost not observed in $\mathrm{TBC} 1$ concrete and $\mathrm{TBC} 2$ concrete. This result proves that resistance against sodium sulfate of mineral admixture is more effective in TBC concrete additionally containing silica fume or fly ash than in OPC concrete and BBC concrete (Table 8).

In case of specimens immersed in $10 \%$ magnesium sulfate solution, the rate of mass decrease in concrete containing mineral admixture was larger than that in $100 \%$ OPC concrete regardless of $\mathrm{W} / \mathrm{B}$. The reason that the rate of mass decrease is higher by magnesium sulfate attack than sodium sulfate attack is because magnesium hydroxide reacts with silica gel and, as a result, C-S-H gradually loses calcium and becomes converted into magnesium silicate hydrates, the nonbinding material $[8,9]$. In this case, resistance against magnesium sulfate attack was found to be higher in the order of OPC, $\mathrm{TBC} 2, \mathrm{TBC}$, and $\mathrm{BBC}$ concrete indicating that use of mineral admixture is disadvantageous. Therefore, caution is required in using mineral admixture when concrete is exposed to magnesium sulfates, such as soil and groundwater.

3.3. XRD Analysis. Figure 4 shows the result of XRD analysis on the sulfate reaction parts of concrete specimens with $\mathrm{W} / \mathrm{B}=43 \%$ immersed in sulfate solution for 365 days. As illustrated by the figure, gypsum and ettringite peaks were formed when specimens were immersed in sodium sulfate solution indicating that these two types of hydrates are the main products of reaction against sodium sulfate attack

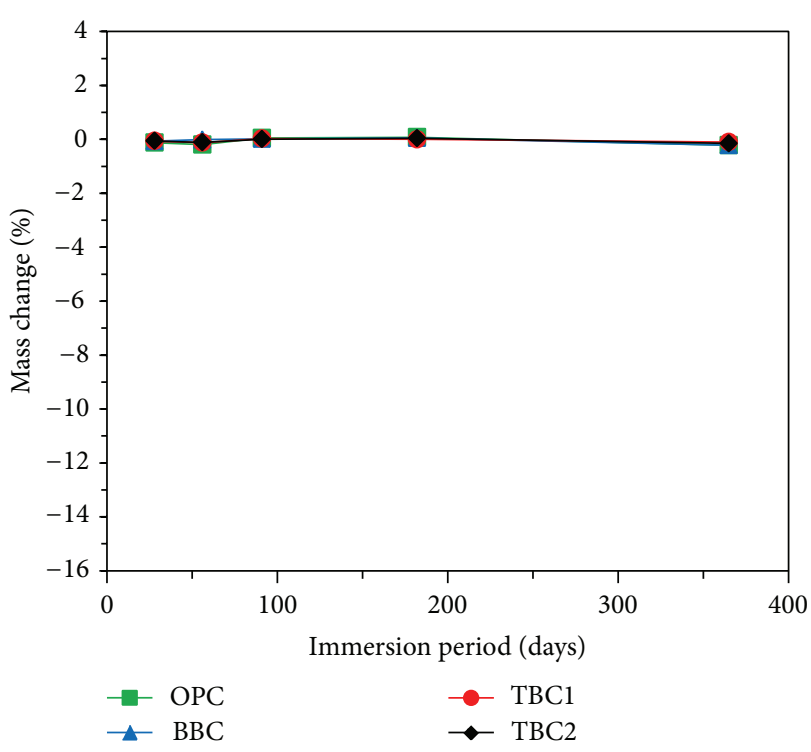

(a) $10 \% \mathrm{Na}_{2} \mathrm{SO}_{4}$

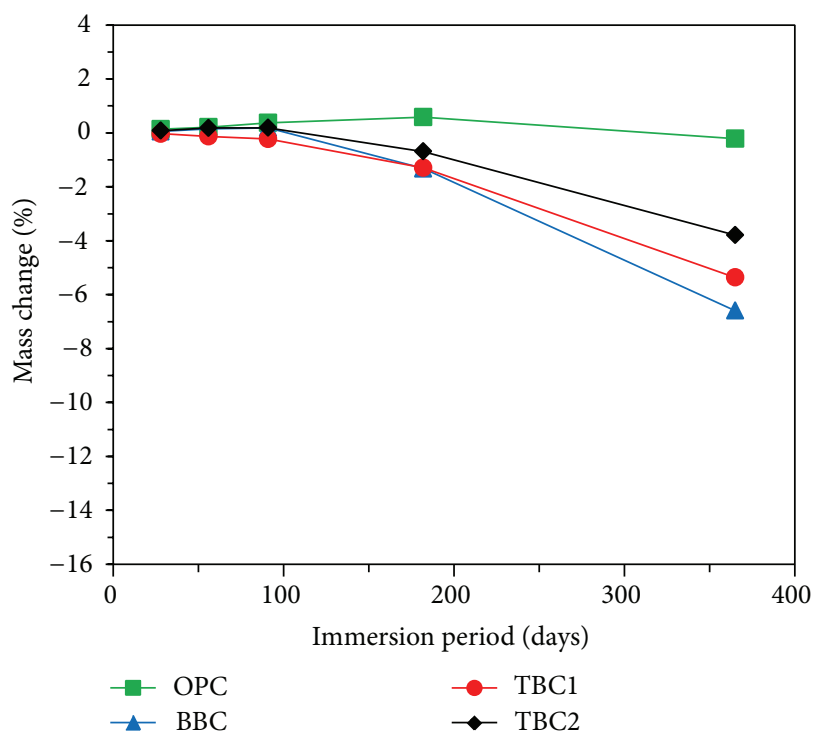

(b) $10 \% \mathrm{MgSO}_{4}$

Figure 2: Mass change of concrete $(\mathrm{W} / \mathrm{B}=32 \%)$.

causing expansion and cracking. In case of immersion in magnesium sulfate solution, brucite of a relatively lower peak was observed in addition to gypsum and ettringite. Brucite is generated by the reaction of hydration products of cement and cation $\left(\mathrm{Mg}^{2+}\right)$ which combines with sulfate ions. It plays a determinant role in magnesium sulfate attack mechanism. Therefore, it was indicated that cation $\left(\mathrm{Mg}^{2+}\right)$ bound with sulfate ions affected the mechanism of magnesium sulfate attack.

\subsection{Mass Change Prediction Model for Sulfate Attack}

3.4.1. Suggestion of Mass Change Prediction Model for Sulfate Attack. As sulfate attack prediction models of concrete, 
TABLE 8: Visual appearance changes with immersion ages.

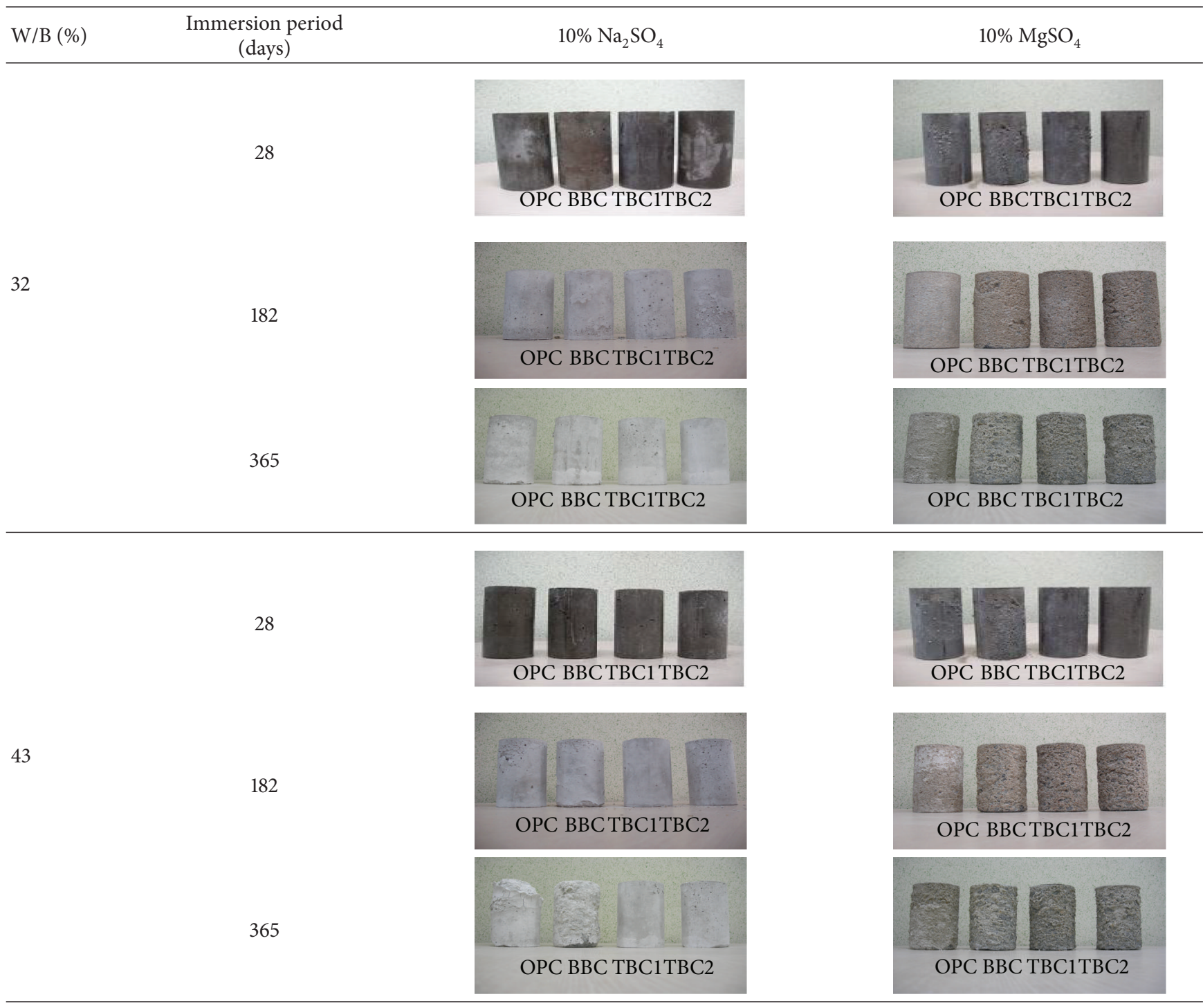

empirical model, mechanistic model, and numerical model are available. However, since the mechanism of sulfate attack is yet to be completely verified, empirical model based on test results is mainly used. Equations (2) and (3) are an empirical model suggested by Kurtis et al. [17]. This is a result of regression analysis on concrete specimens immersed in $2.1 \%$ sodium sulfate solution for 40 years to predict concrete expansion by sulfate attack with $\mathrm{W} / \mathrm{C}$, immersion period, and $\mathrm{C}_{3} \mathrm{~A}$ content as independent variables and concrete expansion amount as a dependent variable. In case $\mathrm{C}_{3} \mathrm{~A}$ content is low, this equation can also be applied to concrete with wide $\mathrm{W} / \mathrm{C}$ range. However, if $\mathrm{C}_{3} \mathrm{~A}$ content is high, the $\mathrm{W} / \mathrm{C}$-related variables are statistically insignificant and therefore $\mathrm{W} / \mathrm{C}$ was not included in the prediction model. Consider

$$
\begin{aligned}
\operatorname{Exp}= & 0.0246+[0.0180(T)(\mathrm{W} / \mathrm{C})] \\
& +\left[0.00016(T)\left(\mathrm{C}_{3} \mathrm{~A}\right)\right]: \mathrm{C}_{3} \mathrm{~A}<8 \%,
\end{aligned}
$$

$$
\begin{aligned}
\operatorname{In}(\operatorname{Exp})= & -3.753+[0.930(T)] \\
& +\left[0.0998 \operatorname{In}(T)\left(C_{3} A\right)\right]: C_{3} A>10 \%,
\end{aligned}
$$

where Exp is percentage of expansion by sulfate attack (\%), $T$ is immersion period (year), $\mathrm{W} / \mathrm{C}$ is water-cement ratio, and $\mathrm{C}_{3} \mathrm{~A}$ is $\mathrm{C}_{3} \mathrm{~A}$ content of cement (\%).

Equation (4) is an empirical model suggested by Jambor [18] of which $\mathrm{W} / \mathrm{B}$ is $60 \%$ and the purpose is to verify behavior of mortar immersed in sodium sulfate solution. In this test, $\mathrm{C}_{3} \mathrm{~A}$ content was $9 \sim 13 \%$. Also, 10 70\% GGBFS and $10 \sim 50 \%$ volcanic tuff were used. As the test solution, sodium sulfate solution with $\mathrm{SO}_{4}$ content of $500 \sim 33,800 \mathrm{mg} / \mathrm{L}$ was used. Using results of measuring amount of sulfates bound by the mortar specimens, mass change, volume change, dynamic modulus of elasticity, compressive strength, and bending strength change of mortar specimens over 4 years, a prediction model for the degree of sulfate-induced corrosion was suggested. In this model, $\mathrm{SO}_{4}$ concentration, immersion period, $\mathrm{C}_{3} \mathrm{~A}$ content, and replacement ratio of 


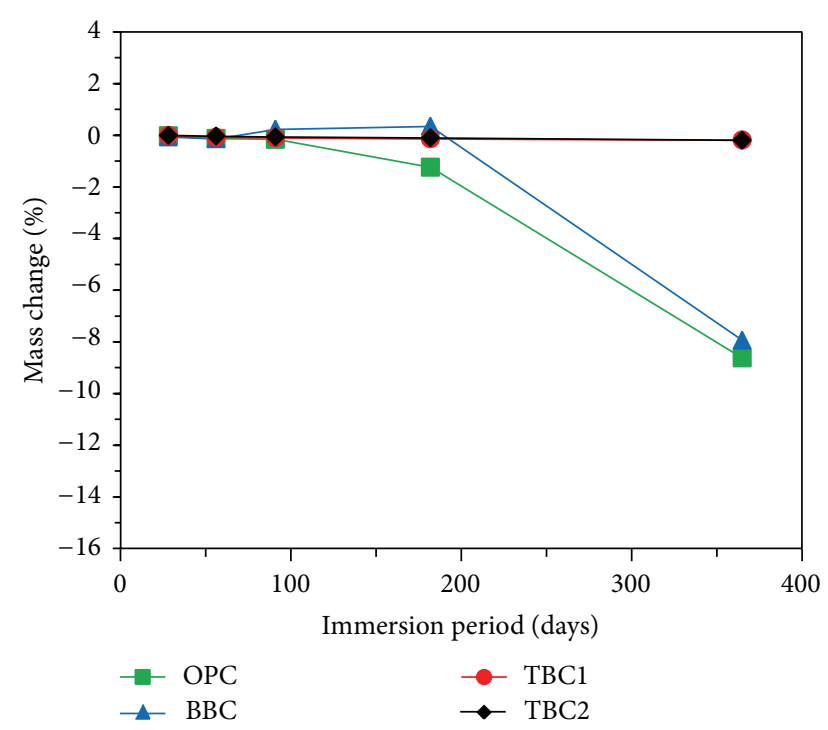

(a) $10 \% \mathrm{Na}_{2} \mathrm{SO}_{4}$

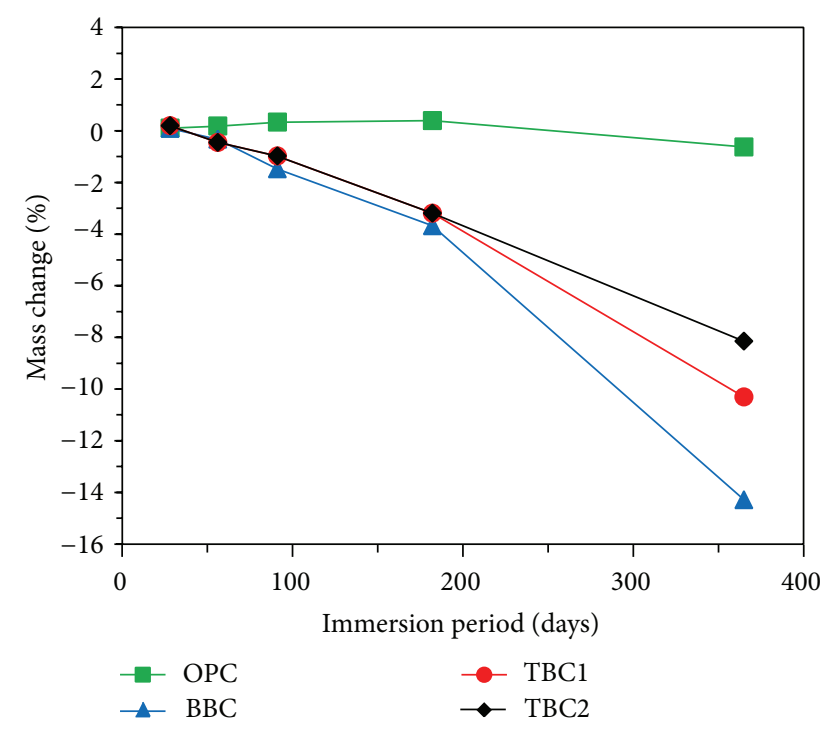

(b) $10 \% \mathrm{MgSO}_{4}$

FIgURE 3: Mass change of concrete $(\mathrm{W} / \mathrm{B}=43 \%)$.

mineral admixture were used as independent variables and degree of sulfate-induced corrosion of mortar was used as a dependent variable. Consider

$$
\mathrm{DC}=e^{-0.016 \mathrm{~A}} \cdot\left[0.11 S^{0.45}\right]\left[0.143 T^{0.33}\right]\left[0.204 e^{0.145 \mathrm{C}_{3} \mathrm{~A}}\right] \text {, }
$$

where DC is degree of sulfate-induced corrosion, $S$ is $\mathrm{SO}_{4}$ concentration $(\mathrm{mg} / \mathrm{L})$ of sulfate solution, $T$ is immersion period (day), $\mathrm{C}_{3} \mathrm{~A}$ is $\mathrm{C}_{3} \mathrm{~A}$ content of cement (\%), and $A$ is replacement ratio of mineral admixture (binder mass \%).

In this study, mass changes of concrete specimens immersed in $10 \%$ sodium sulfate solution and $10 \%$ magnesium sulfate solution for 1 year were measured per age of immersion and, based on the existing empirical model of (2), a prediction model for mass change by sulfate attack was suggested as of (5) (8). To determine coefficients of this model, regression analysis was conducted using SAS (statistical analysis system) [19], a general statistical program, with immersion period, $\mathrm{W} / \mathrm{B}$, and $\mathrm{C}_{3} \mathrm{~A}$ content of concrete as independent variables and mass change as a dependent variable.

(i) Concrete immersed in sodium sulfate solution for $100 \%$ OPC concrete is

$$
\begin{aligned}
\mathrm{MC}=-\exp [ & -5.997+1.455\left(T^{0.5}\right)(\mathrm{W} / \mathrm{B}) \\
& \left.-0.00165(T)\left(\mathrm{C}_{3} \mathrm{~A}\right)\right] \quad\left(R^{2}=0.98\right) ;
\end{aligned}
$$

for BBC concrete and TBC concrete:

$$
\begin{aligned}
\mathrm{MC}=-\exp [ & -3.131+0.088(T) \operatorname{In}(\mathrm{W} / \mathrm{B}) \\
& \left.+0.076(T) \operatorname{In}\left(\mathrm{C}_{3} \mathrm{~A}\right)\right] \quad\left(R^{2}=0.77\right) .
\end{aligned}
$$

(ii) Concrete immersed in magnesium sulfate solution for $100 \%$ OPC concrete is

$$
\begin{aligned}
\mathrm{MC}=[ & 0.586-0.00525(T)(\mathrm{W} / \mathrm{B}) \\
& \left.-0.078 \operatorname{In}(T)\left(\mathrm{C}_{3} \mathrm{~A}\right)\right] \quad\left(R^{2}=0.50\right) ;
\end{aligned}
$$

for $\mathrm{BBC}$ concrete and $\mathrm{TBC}$ concrete:

$$
\begin{aligned}
\mathrm{MC}=-\exp [ & -0.466+0.007(T) \operatorname{In}(\mathrm{W} / \mathrm{B}) \\
& \left.+0.0046(T)\left(\mathrm{C}_{3} \mathrm{~A}\right)\right] \quad\left(R^{2}=0.83\right),
\end{aligned}
$$

where MC is mass change of concrete by sulfate attack (\%), $T$ is immersion period (day), $\mathrm{W} / \mathrm{B}$ is water-binder ratio, and $\mathrm{C}_{3} \mathrm{~A}$ is $\mathrm{C}_{3} \mathrm{~A}$ content of concrete (\%).

\subsubsection{Verification of Mass Change Prediction Model.} Figures 5 and 6 summarize comparison of the test results of mass change of concrete specimens immersed in sulfate solution with mass change prediction values using the model suggested in this study. As illustrated by the figures, the test results and mass change prediction values of the model suggested in this study correspond relatively well, indicating that prediction of mass change by sulfate attack with a relatively high reliability can be achieved using the model suggested in this study.

Figure 7 compares mass change prediction result using the model suggested in this study with result of the existing model of (4) to predict the degree of sulfate-induced corrosion, in case of concrete immersed in $10 \%$ sodium sulfate solution per immersion period. Despite following a similar trend as a whole, the results have slight differences. This is because while the existing model of (4) predicts a general degradation of mortar according to mass and volume change, strength, and dynamic modulus of elasticity, the suggested model predicts only the mass change of concrete by sulfate attack and therefore test conditions and variables are different. 


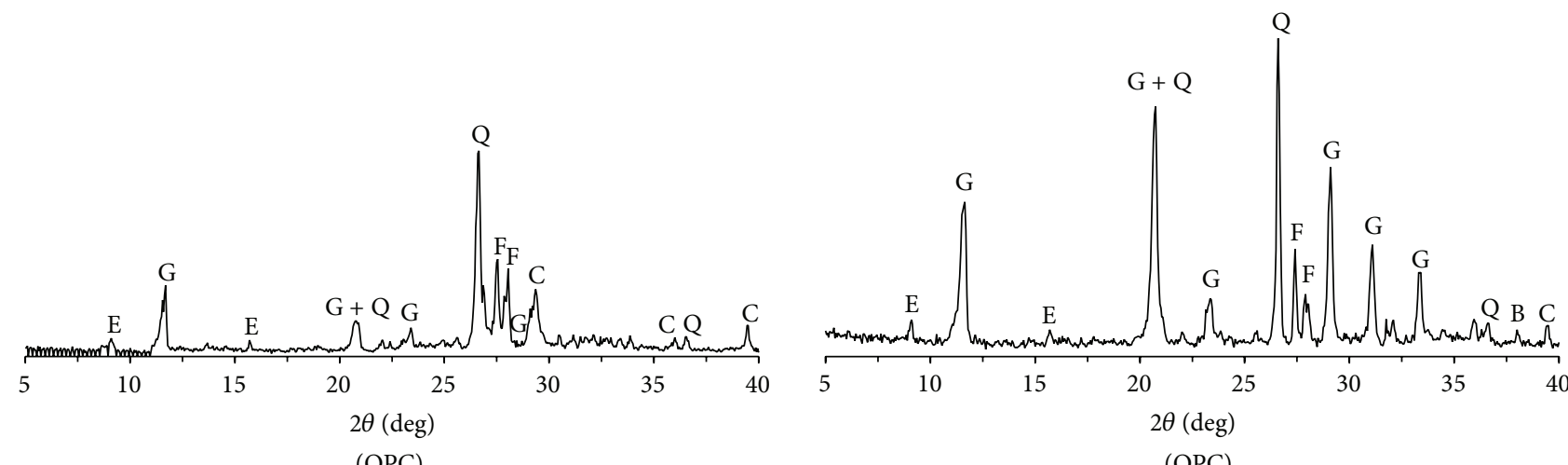

(OPC)

(OPC)

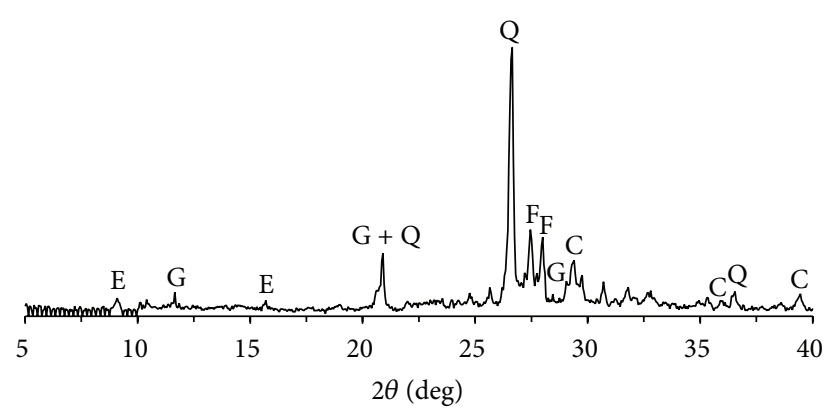

(BBC)

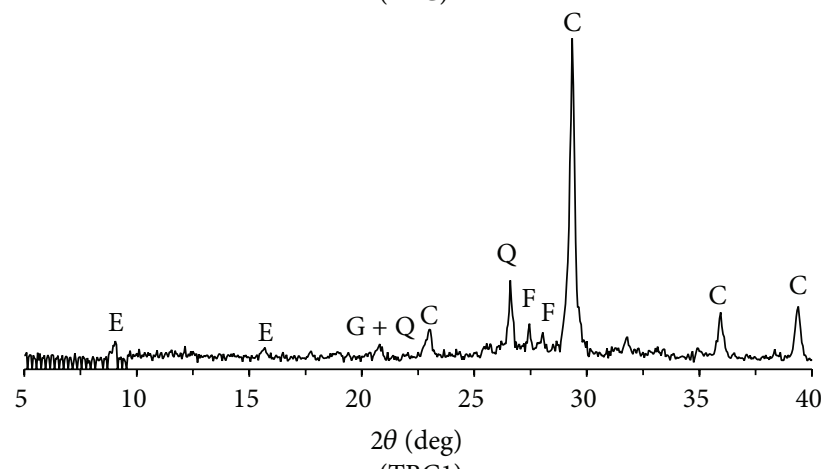

(TBC1)

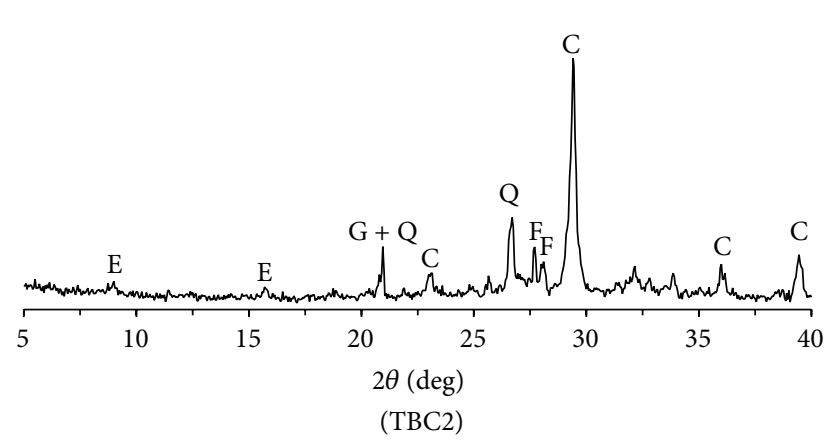

(a) $10 \% \mathrm{Na}_{2} \mathrm{SO}_{4}$

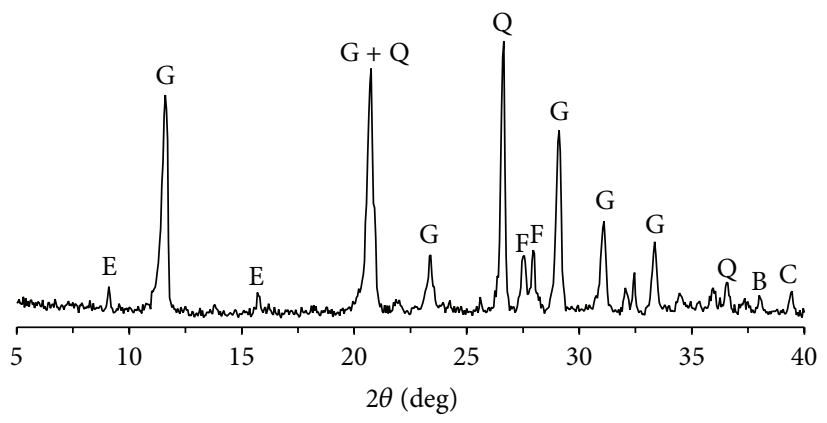

(BBC)

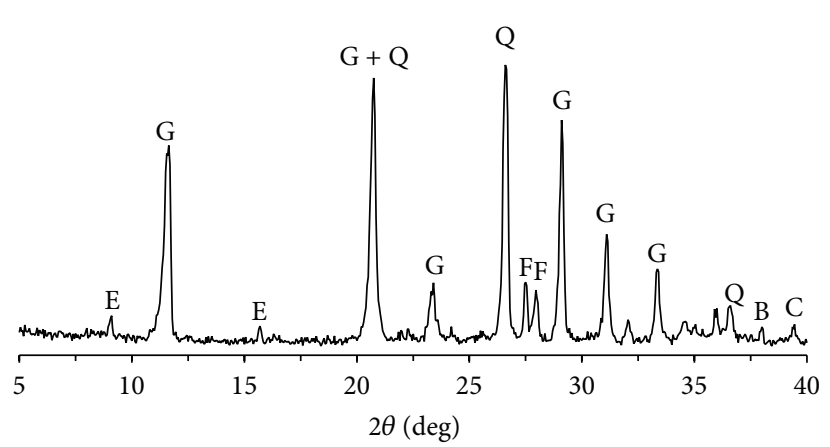

(TBC1)

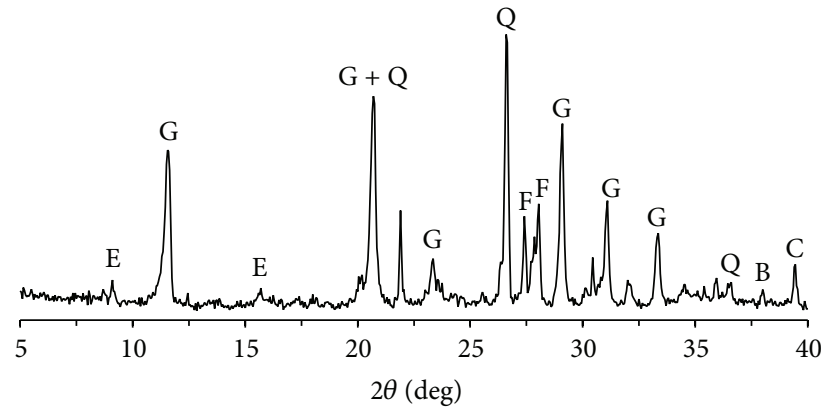

(TBC2)

(b) $10 \% \mathrm{MgSO}_{4}$

FIGURE 4: XRD analysis results of concrete specimens (G: gypsum, E: ettringite, B: brucite Q: quartz, C: calcite, and F: feldspar). 


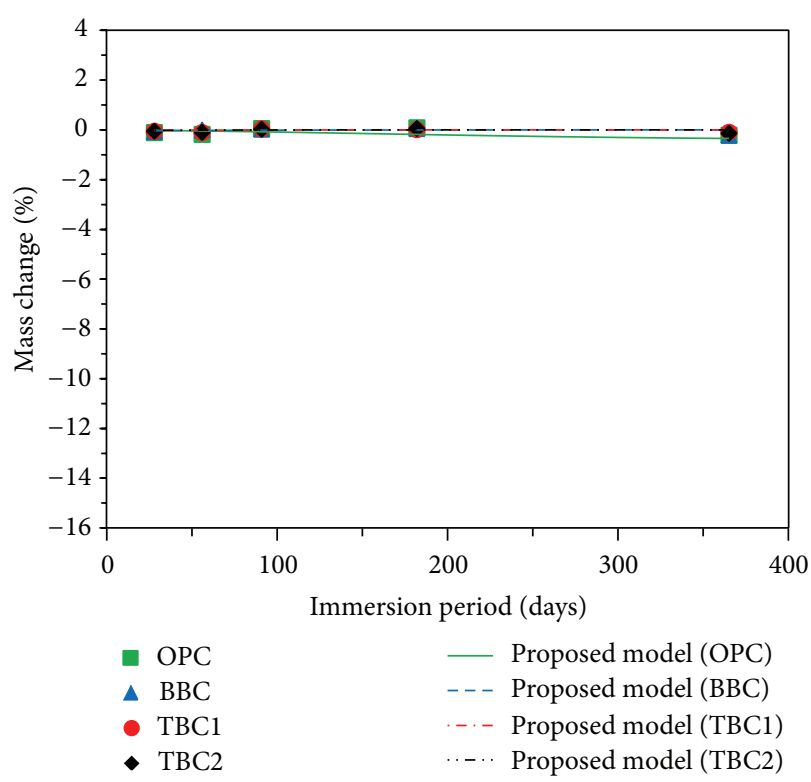

(a) $\mathrm{W} / \mathrm{B}=32 \%$

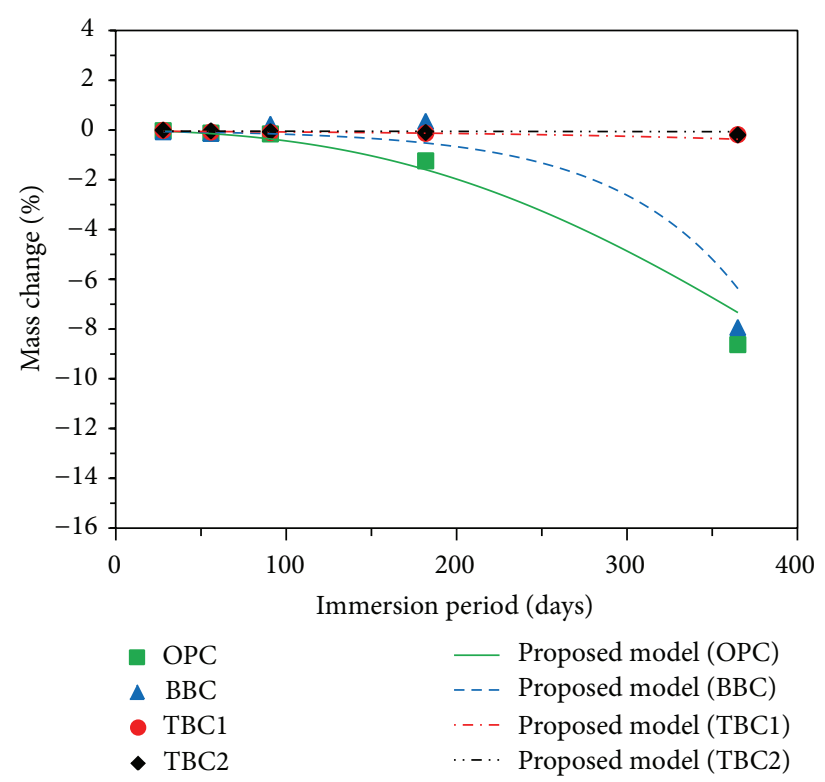

(b) $\mathrm{W} / \mathrm{B}=43 \%$

FIGURE 5: Comparison of the measurements and predictions $\left(10 \% \mathrm{Na}_{2} \mathrm{SO}_{4}\right)$.

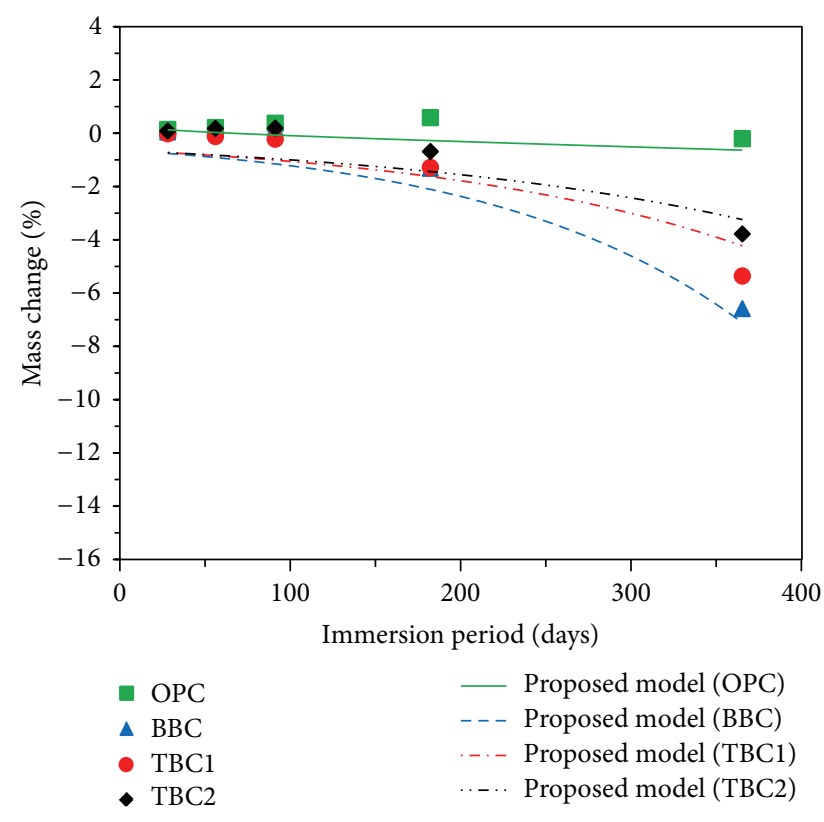

(a) $\mathrm{W} / \mathrm{B}=32 \%$

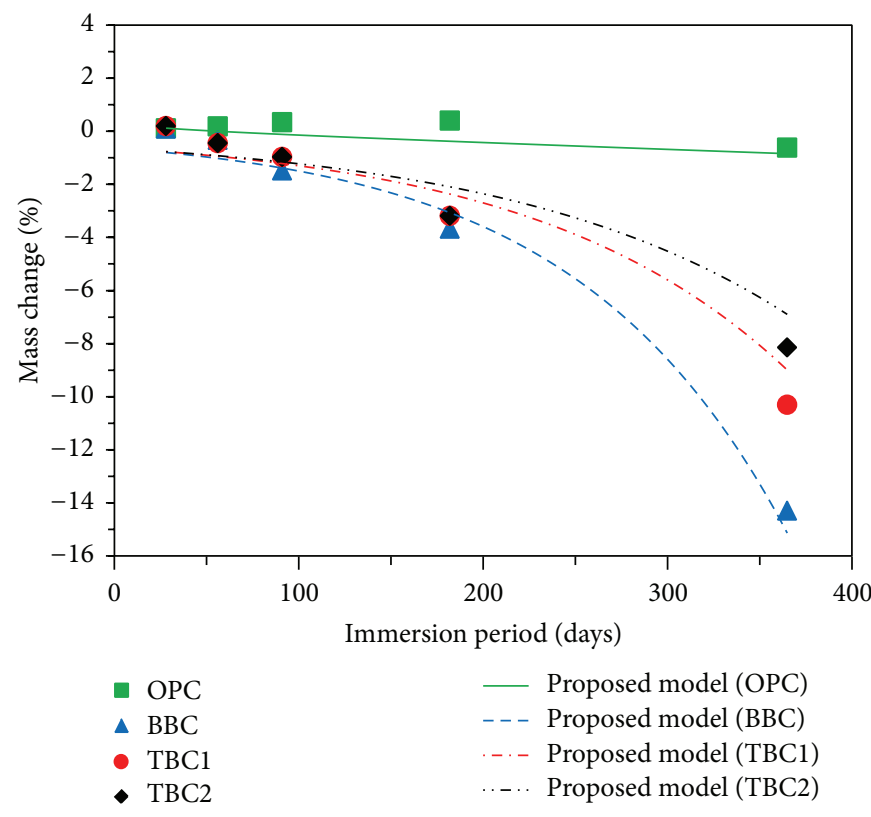

(b) $\mathrm{W} / \mathrm{B}=43 \%$

FIGURE 6: Comparison of the measurements and predictions $\left(10 \% \mathrm{MgSO}_{4}\right)$.

\section{Conclusions}

The following conclusions were drawn from the experimental study on the mass change of concrete subjected to sulfate attack.

(1) In case of immersion in $10 \%$ sodium sulfate solution, almost no mass change was observed in all of the concrete specimens regardless of the use of mineral admixture when $\mathrm{W} / \mathrm{B}$ was $32 \%$. This is because the low $\mathrm{W} / \mathrm{B}$ increased density of concrete microstructure and therefore slowed down degradation by sodium sulfate attack. When W/B was $43 \%$, the rate of mass decrease in $100 \%$ OPC concrete and BBC concrete specimens was found to be higher as the age of immersion increased. However, there was almost no mass decrease of $\mathrm{TBC} 1$ concrete and $\mathrm{TBC} 2$ concrete. 


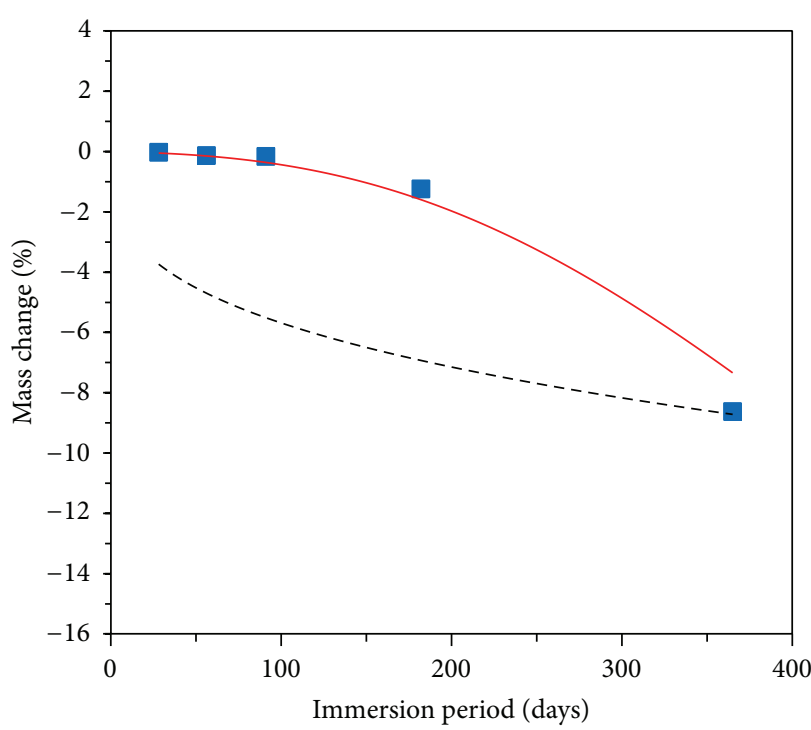

- Experimental results

- Proposed model (Eq. (5))

- - Jambor's model (Eq. (4))

(a) OPC concrete

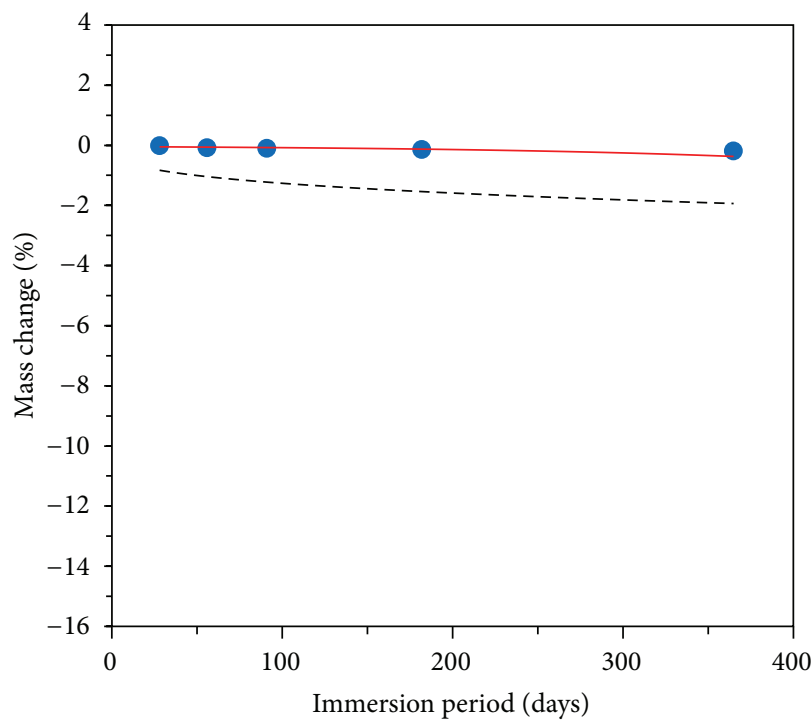

- Experimental results

- Proposed model (Eq. (6))

- - Jambor's model (Eq. (4))

(c) $\mathrm{TBC} 1$ concrete

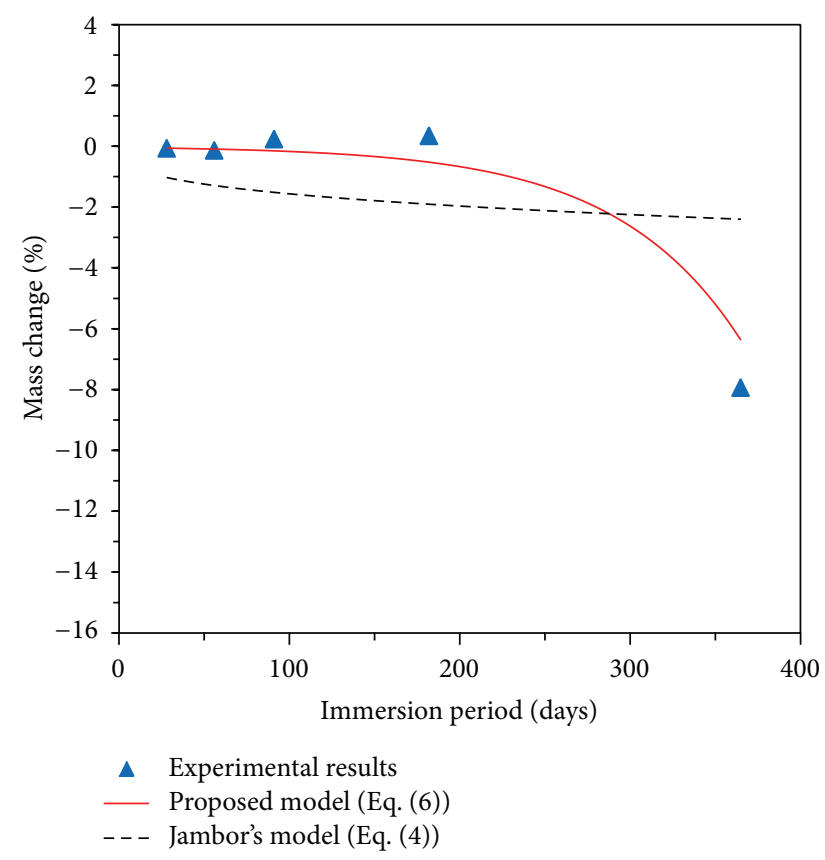

(b) $\mathrm{BBC}$ concrete

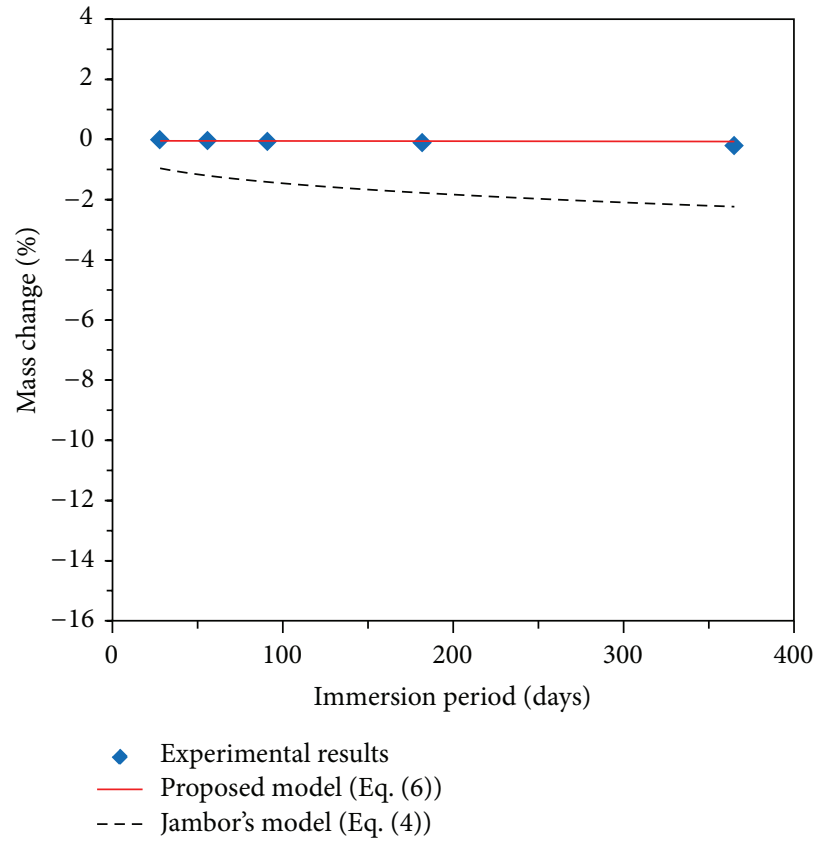

(d) TBC2 concrete

FIGURE 7: Comparison of results predicted by proposed model and Jambor's model (W/B $\left.=43 \%, 10 \% \mathrm{Na}_{2} \mathrm{SO}_{4}\right)$.

This proves that the resistance of mineral admixture against sodium sulfate was greater in TBC than in BBC.

(2) In case of immersion in $10 \%$ magnesium sulfate solution, the rate of mass decrease of concrete containing mineral admixture was found to be higher than OPC concrete regardless of W/B. This is because pozzolanic reaction of mineral admixture consumes calcium hydroxide and resultantly lowers the C-S-H protection effect of calcium hydroxide at magnesium sulfate attack. Therefore, it is necessary to take caution in using mineral admixture when concrete is exposed to the magnesium sulfate environment, such as soil and groundwater.

(3) Based on the test results, a prediction model for mass change of concrete by sulfate attack was suggested and 
it was found that the test results and predictions by the suggested model corresponded relatively well. To further generalize sulfate attack prediction model, it will be necessary to pursue studies on sulfate resistance test and mechanistic and numerical methods by considering a variety of influential factors.

\section{Conflict of Interests}

The authors declare that there is no conflict of interests regarding the publication of this paper.

\section{Acknowledgments}

This research was supported by "the Center for Concrete Korea" and "04KIBANKUCHOOKA02" sponsored by Ministry of Land, Infrastructure, and Transport of Korea. This support is gratefully acknowledged.

\section{References}

[1] P. K. Mehta, "Mechanism of sulfate attack on portland cement concrete-another look," Cement and Concrete Research, vol. 13, no. 3, pp. 401-406, 1983.

[2] T. H. Wee, A. K. Suryavanshi, S. F. Wong, and A. K. M. Anisur Rahman, "Sulfate resistance of concrete containing mineral admixtures," ACI Materials Journal, vol. 97, no. 5, pp. 536-549, 2000.

[3] M. A. Shazali, M. H. Baluch, and A. H. Al-Gadhib, "Predicting residual strength in unsaturated concrete exposed to sulfate attack," Journal of Materials in Civil Engineering, vol. 18, no. 3, pp. 343-354, 2006.

[4] A. Cavdar and S. Yetgin, "Investigation of mechanical and mineralogical properties of mortars subjected to sulfate," Construction and Building Materials, vol. 24, no. 11, pp. 2231-2242, 2010.

[5] P. S. Mangat and J. M. Khatib, "Influence of fly ash, silica fume, and slag on sulfate resistance of concrete," ACI Materials Journal, vol. 92, no. 5, pp. 542-552, 1995.

[6] O. S. B. Al-Amoudi, "Mechanisms of sulfate attack in plain and blended cements: a review," in Proceedings of the Conference Extending Performance of Concrete Structures. International Congress "Creating with Concrete", pp. 247-260, Dundee, UK, 1999.

[7] N. Shanahan and A. Zayed, "Cement composition and sulfate attack: part I," Cement and Concrete Research, vol. 37, no. 4, pp. 618-623, 2007.

[8] M. Santhanam, M. D. Cohen, and J. Olek, "Mechanism of sulfate attack: a fresh look: part 1: summary of experimental results," Cement and Concrete Research, vol. 32, no. 6, pp. 915-921, 2002.

[9] M. Santhanam, M. D. Cohen, and J. Olek, "Mechanism of sulfate attack: a fresh look part 2 : proposed mechanisms," Cement and Concrete Research, vol. 33, no. 3, pp. 341-346, 2003.

[10] N. Yoshida, Y. Matsunami, M. Nagayama, and E. Sakai, "Salt weathering in residential concrete foundations exposed to sulfate-bearing ground," Journal of Advanced Concrete Technology, vol. 8, no. 2, pp. 121-134, 2010.

[11] S. U. Al-Dulaijan, "Sulfate resistance of plain and blended cements exposed to magnesium sulfate solutions," Construction and Building Materials, vol. 21, no. 8, pp. 1792-1802, 2007.
[12] S. Goyal, M. Kumar, D. S. Sidhu, and B. Bhattacharjee, "Resistance of mineral admixture concrete to acid attack," Journal of Advanced Concrete Technology, vol. 7, no. 2, pp. 273-283, 2009.

[13] H. N. Atahan and D. Dikme, "Use of mineral admixtures for enhanced resistance against sulfate attack," Construction and Building Materials, vol. 25, no. 8, pp. 3450-3457, 2011.

[14] JSTMC 7401, Method of Test for Chemical Resistance of Concrete in Aggressive Solution, Japanese Industrial Standard, Tokyo, Japan, 1999.

[15] ASTM, "Standard test method for length change of hydrauliccement mortars exposed to sulfate solution," ASTM C 1012, American Society for Testing and Materials, 2007.

[16] S. H. Bae, Y. S. Chung, K. S. Park, and J. G. Lee, "An experimental study on the properties of admixtures for concrete," Journal of Korea Concrete Institute, vol. 11, no. 2, pp. 115-125, 1999.

[17] K. E. Kurtis, P. J. M. Monteiro, and S. M. Madanat, "Empirical models to predict concrete expansion caused by sulfate attack," ACI Structural Journal, vol. 97, no. 2, pp. 156-161, 2000.

[18] J. Skalny, J. Marchand, and I. Odler, Sulfate Attack on Concrete, pp. 153-160, Spon Press, 2002.

[19] SAS Institute, Statistical Analysis Systems (SAS), Version 9.1.3, SAS Institute, Cary, NC, USA, 2002. 


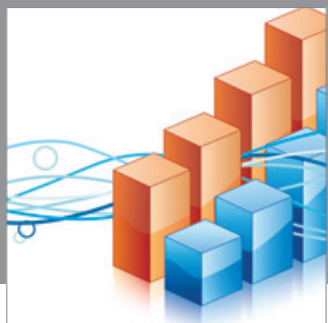

Advances in

Operations Research

mansans

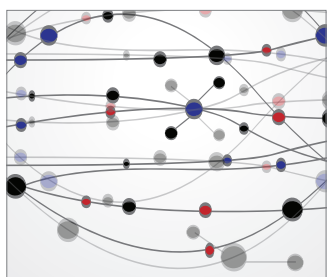

The Scientific World Journal
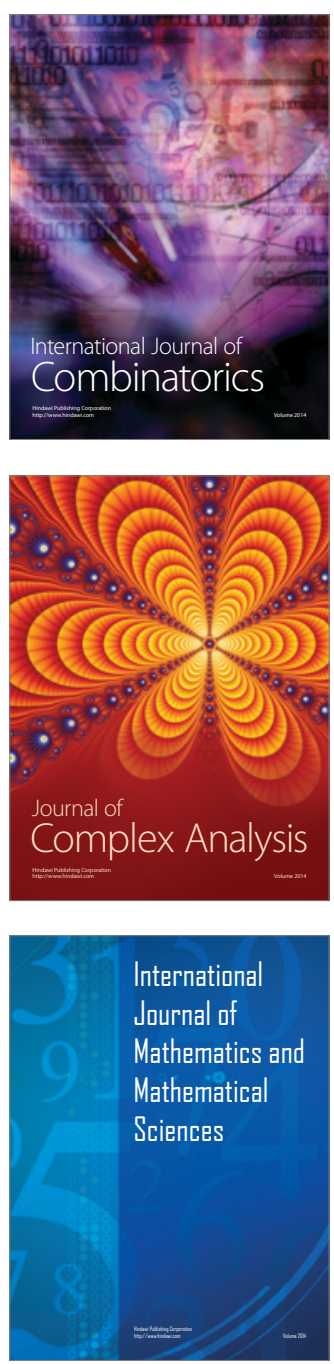
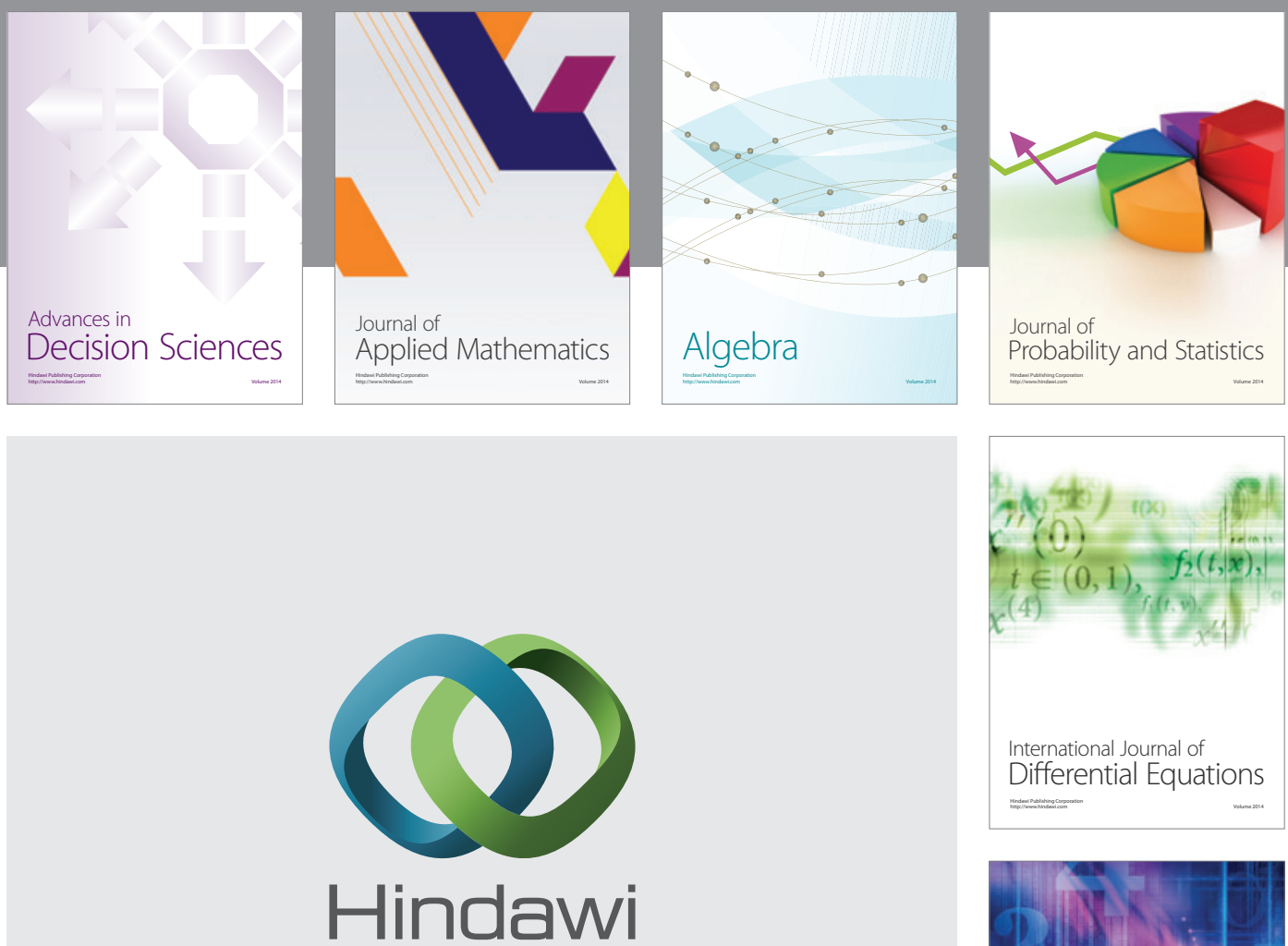

Submit your manuscripts at http://www.hindawi.com
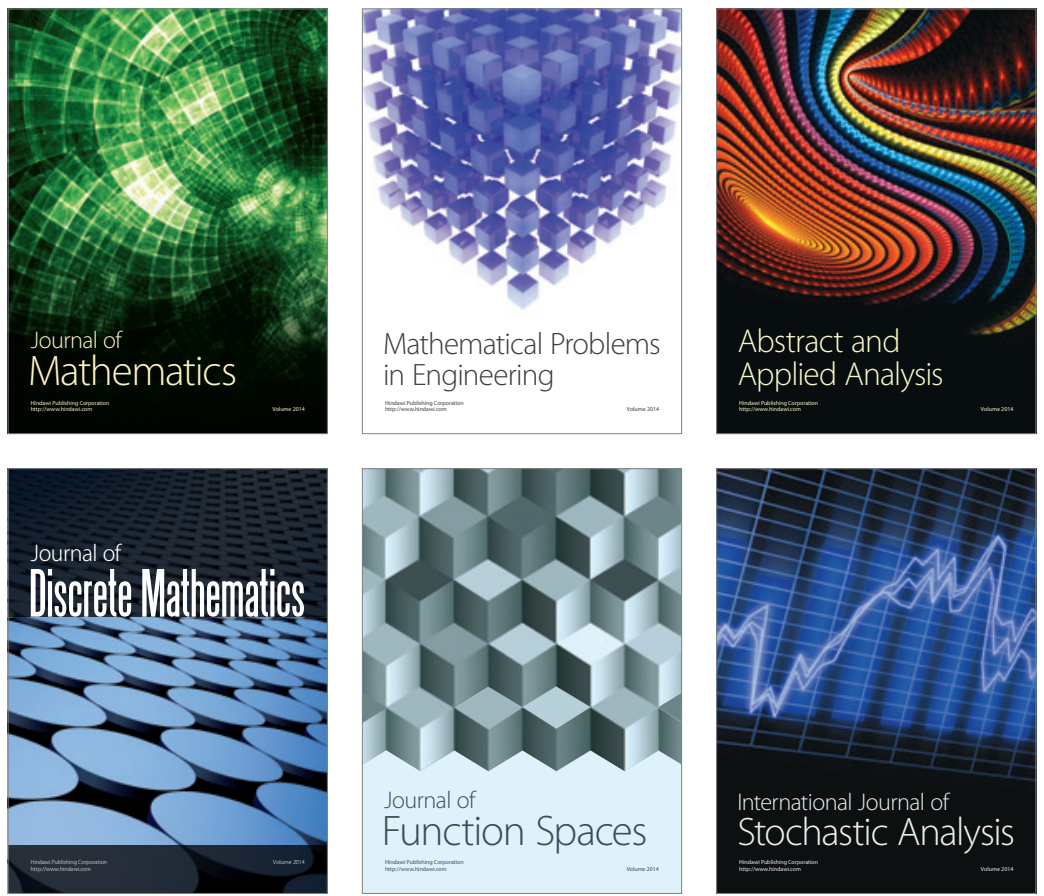

Journal of

Function Spaces

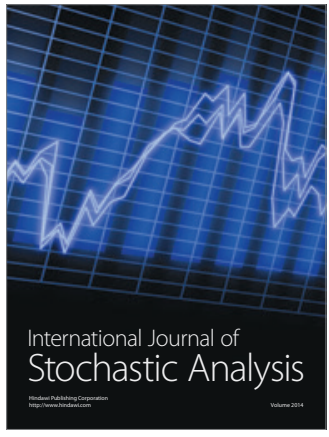

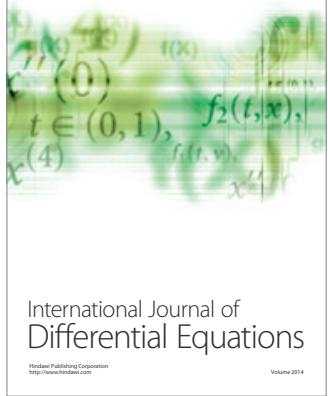
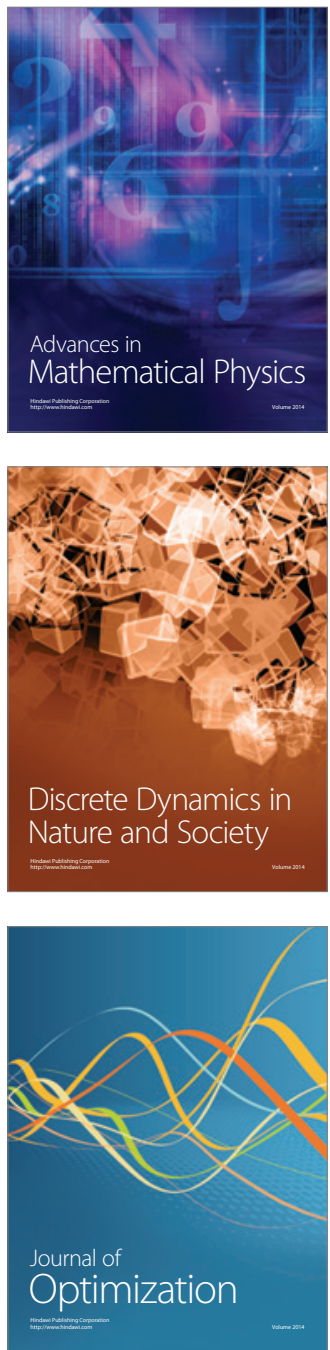